\title{
The Moderating Effect of Government Policy on the Relationship between Revenue Collection Practices and Financial Accountability of Rorya District Council in Tanzania
}

Charles Kitamuru Chacha ${ }^{1 *}$, Dr. Andrew Nyangau $(\mathrm{PhD})^{2}$, Dr. Mong'are Omare $(\mathrm{PhD})^{3}$

${ }^{1,2}$ Lecturer, Department of Accounting and Finance

${ }^{3}$ Lecturer, Department of Strategic and Human Resources Management School of Business and Economics Kisii University Kenya

DOI: $10.36348 /$ sjef.2021.v05i03.004

| Received: 26.12.2020 | Accepted: 11.01.2021 | Published: 30.03.2021

*Corresponding author: Charles Kitamuru Chacha

Abstract

Based on local government medium term expenditure framework (MTEF) model, financial accountability results is a continuous set of activities and operations related with provision of goods and services to customers and benefits accumulated from payments of goods and services. The purpose of study was to analyze the effects of revenue collection on financial accountability of Rorya District Council in Tanzania. The specific objective was to analyze the effect of cess collection on financial accountability in Districts Council in Tanzania. The study used cross-sectional survey research design. The target population of 760 Rorya District council members was used. Stratified sampling technique was used to determine the sample size of 288 respondents. Closed ended questionnaire was used to collect primary data arranged using 5 point scale likert scale. Descriptive statistics was used to analyze data and inferential to make inferences. The result was presented by tables and figures. The study found that cess collection was from fishing (Sangara) and was well achieved. The study recommended that cess collection revenues should be improved by the set target compatible with all customer fees. Further, the study recommends further research can be done on the impact of revenue collections in rural and urban local authorities in developing countries.

Keywords: Financial accountability, cess collection, Rorya District Council in Tanzania.

Copyright () 2021 The Author(s): This is an open-access article distributed under the terms of the Creative Commons Attribution 4.0 International License (CC BY-NC 4.0) which permits unrestricted use, distribution, and reproduction in any medium for non-commercial use provided the original author and source are credited.

\section{INTRODUCTION}

\section{Background of the Study}

Revenue collection policy in modern forms begun in England with commissioner of revenue England in federal government in $17^{\text {th }}$ century to address the problem of war financing and permanent institution building for that purpose, England was the first country to discover revenue collection through tax which takes form of grants in the current days in the world [1]. Land tax was the first revenue collection source taken then later different excise taxes started during $17^{\text {th }}$ century where many revenue resources were designed to finance Oliver Cromwell's war. The policy and procedures implementation was later adopted and amended during American Civil War in 1862 by President Abraham Lincoln who passed revenue Act of 1862 to apply the direct revenue collection policy through creation revenue commissioner's office to enact income tax payable by individual and groups [2].

In Mexico revenue collection policy is compulsory payment from local governments as every
Tenth District state depends on the amount collected to the state government annually, but the magnitude of this reliance ranges from low percentage of 17 percent in Nebraska to a high percentage of 49 percent in New Mexico. Central Government policy on State revenue transfer includes state aid for local schools, roads, sewers, health programs, and public welfare. This category also includes $\mathrm{s}$ state aid for public utility projects. In the major revenue source for grants to local government comes from the Central Government in the form of Financial Assistance Grants. The Government pays attention to collection of revenue to state governments and for distribution to local community via State Grants Commissions from local government revenue collection [3].

In Egypt, only few mention revenue obtained from public lands extra acted kinds of economic activities taking place, the labor required and ownership of means of production, the distribution of revenue based on haves and have not of land. During the middle age public revenue was derived largely from public lands owned by crown, local land or bishop's grid 
supplementations from contributions in kind of various form of taxation. According to Rosen et al. [4] early system of public finance often taxed a variety of goods and activities, including property, trade and sometimes wealth. Administrators in England attempted to collect the first true income tax, a tax on wages, but the public quickly demanded to repeal and all tax records were burned. Modern forms of tax collection date to a British income levied in tax raised revenue for the Napoleonic wars against France and a coalition of other European nations won by the accepted income tax [5].

In Morogoro revenue authority, revenue collection has not reached budget for several years due to challenges ranging from low tax morale on tax payers [6]. The level of revenue collection knowledge is influenced among tax payers, application on new technology unknown to most tax payers, low land of arrears recovery and proper assessment while enabling tax payers and assessors in tax cost [7].

Cess collection from produce crops includes providing tax assistance to taxpayer per suing or resolving erroneous and fraudulent in tax filling. The collection has been overseen different revenue programs enforced rates of affordable care revenue collection act. Cess was known as tax on the movement of agricultural produces raised by local government authorities to imply surplus for business undertakings. The efficiency cess collections improves overall revenue collections in government and its Act is directed to $80 \%$ of cess collected to utilize in improving roads,infrastructures and social amenities in agriculture sectors of the given period of time [8].

Cess collection has resulted to very high revenue collection among agricultural producers. It has resulted to the use of large amount in inputs, but experience small benefit not only margins of return from agriculture products but also become lower than expected in profits. As a result the high cost of agricultural production is compared to actual revenue discourages for their agricultural production and hence reduce cess collection in Local Government Authorities. Cess collection are Limited by human and institution capacity of Local level and tendencies of tax evasion featuring from the indicators of Local Official of uncollected Central Government through Minister of Agricultural on the financial year 2018/2019 abolished cess collection from small production and decreased the rate of charging in order to motivate agricultural performance and improve agricultural income [9].

Financial accountability improves quality of financial information embraces key aspects such as relevance, reliability, understandability accuracy and timelines. These qualities of financial information have significant contribution the quality financial reporting. Reforming PFM System needs to be properly planned to ensure that governments have available needs resources. Most countries face similar set of challenges. This includes having to update existing laws and regulations, identifying and valuing revenue collection [10]. Government must be aware of how to most effectively achieve change over the medium term if in the planning stage, there seems to be a great deal to be done to support reform, that simply high lights the poor state of their existing PFM System and therefore, the greater need to improve their financial management processes. They should go a long way to improve performance within the sector and consequently improve trust and confidence a political institutions [11].

\section{Statement of the Problem}

The sustainable achievement of internal balanced budget of Local Government Authorities in Tanzania is mostly extent of moderating effects for Government policies on revenue collections and financial accountability. When cess collection is moderated by Government policies they would improve financial accountability at district councils in Tanzania.

In practice, financial accountability of Rorya district council in the previous years has not improved. These can be witnessed by loss of funds, delays in legal actions on victims of loss at all levels, no action taken to civil servant and politicians who involve on that scandals, misappropriations reports, poor management of policies and extremes' level of negligence from various authorities. There is loss of funds in revenue collected from fishing vessels landing fees was Tshs $40,176,000$ in the year 2012, Tshs 49,776,012 in the year 2013 (Auditor report, 2011/2012). Revenue collection which was not banked in the year 2014 was Tshs 45,038,238.20; in the year 2015 was Tshs. $45,000,218.10$, in the year 2017 remained low by Tshs $44,709,000$ which is below average (Controller and Auditor General Reports, 2017/2018). Budgeted funds not accounted for allocated to development activities Tshs 334,272,704, Tshs 440,709,000 in the year 2017 and 2018 respectively.

Pieters [12] evaluated the challenges facing revenue collection on resource allocation accountability in NDlambe local Municipality in Eastern Cape Province. The study sought to evaluate tax challenges, poor revenue collection, strategies and allocation of revenue on service delivery of Ndlambe local municipality in South Africa. The study failed to evaluate license collection as in important revenue collection on improving financial accountability. Thus, the study aimed to analyze the moderating effect of government policy on the relationship between revenue collection and financial accountability in Rorya District Council, Tanzania by this research.

\section{OBJECTIVES OF THE STUDY} Specific Objectives

The study addressed the following specific objectives to; 
- Analyze the effect of cess revenue collection on financial accountability in Rorya District Council in Tanzania.

\section{LITERATURE REVIEW \\ Theoretical Review \\ Revenue diversification theory}

This theory was developed in 1966 by Katz and Kahn. Diversification of revenue emphasizes on how government can diversify and balance collection criteria as portfolio increases. The strategies used to collect revenue are changing with technology on financing government projects [13]. The commercial market orientation has positive influence on revenue collection. The sources of revenue exist with similar complaints about multiple incomes from each business and individuals. Propositions that revenue collection is for social advantage to the community treated as an irrelevant [2].

The theory assumes that organizations such as institutions and Governments entities like other open systems needs to engage in a variety of modes of exchange with the situation. It posts the considerations of the relationships between organization and its environment and what goes on in the organization. The theory is mostly about connection of structure and constant attributes of revenue collections. The basic idea lies on the central systems theory as the conceptual interactions [14].

The theory is criticized that revenue collection is based on the ability to collect and hence quid pro quo in underlying as an individual sacrifice [15]. This sacrifice raised is what one has sacrificed on equal sacrifice implied that tax paid is equal. The theory holds that tax is language to the way people speak about tax while in reality tax depends on cash flow for every tax burden imposed. The revenue collection was characterized by the general tax burden on individuals' income.

This theory is relevant in this study as it explains the importance of raising revenue from business through taxation. It provides the basis to which revenue collection is inherent power of government to impose taxes, identifying the means of taxations. The revenue is diversified through revenue collection coming from transfer of property, government finances. It plays a major role in measuring distribution of resources which are diverse and requires government to implement revenue function. This would explain revenue collection and financial accountability.

\section{EMPIRICAL LITERATURE}

\section{Cess Collection and Financial Accountability}

Wohlibier [16] carried a study on cess collection on financial accountability of organizations in European commission. The study focused on cess collection policy issues on financial accountability of organizations. Descriptive research design was used on the target population of 65 organizations under European commissions. Correlation analysis was used to analyze primary data which found that cess collection contribute highly to public finance for sustainable growth. Descriptive statistics showed that cess revenue was stabilizer inherent to economic growth. Also the reversal of cess collection is a negatively correlated from asset prices and discretionary measures demand. Despite this cess collection efficiency has not been only correlated by other financial accountability areas.

Akabzaa [17] conducted a study of the implication of cess collection and financial accountability of organizations in Newyork. The aim was to investigate the implication of cess collection as a tool for national development and poverty reduction in NewYork. Using factor analysis, it was found that cess collection positively affect financial accountability of levies by companies. Cess collection reforms broaden the increases revenue collection. The study did not analyze revenue collected from cotton crop cess, Fishing cess (sangara) and Milk cess on financial accountability. However, the study failed to examine cess collection from 2002 to 2008 where countries have mobilized financial accountability.

Harrison [18] studied cess collection and financial accountability in the mining sector of Ghana. The purpose of the study was to assess the impact of fiscal regimes in the mining sector in Ghana on cess collection using buoyancy ratios. The study used single method of dummy variables was correlated in order to adjust discretionary to compute revenue collected. The empirical findings showed that cess collection makes agricultural produce high tax estimate in financial accountability. Further, the results indicated that discretionary tax measures are effective in financial accountability more in tax revenues and that financial accountability was reasonable during the period. Food crop cess and produce cess had positive relationship between cess revenue collection and financial accountability. Despite there is no successful cess collection in the revenue collection and the gap is widened.

Munene and Nduruhu [19] did a study on the effect of cess collections on financial accountability of customs and border control department of Kenya revenue authority. The study aimed to examine the effect of cess collections on financial accountability at customs and border control department of Kenya revenue authority. The sample of 3564 firms were examined with descriptive statistics which found that cess collection facilitate financial accountability period which lies at the heart of economic crisis. The study also adds that Kenya has experienced a significant change in financial accountability its economy over the last four years of cess collections. Despite, the undoubted intentions are still observed in Kenya revenue authority. The predictive effect of customs 
enforcement reforms in cess collection is a weak positively correlated but not significant to financial accountability. Despite many factors affecting revenue collection, cess collections have not been examined exhaustively.

Gekonge [1] researched on the impact of cess collections on financial accountability in Nyeri County. The aim of the study was to investigate the effect of cess collection and financial accountability. Descriptive using Mean and standard deviation was used for data analysis which established that identification number for cess collections lacks reforms proper handling. Cess taxation system had impact on financial accountability rolled out in 2013 revenue collection targets. Cess collection system is enhanced through the Business Process Improvement (BPI) efficiency.

\section{Government Policy and Financial Accountability}

Emad [20] examined the relationships between government policy and financial accountability of firms. The study was conducted in Iraq and it aimed at determining how government policy affects financial accountability. A sample of 34 respondents was determined by census of all business firms in SMEs. Correlation analysis and one independent sample test was conducted to analyze data. The study found that government policy contributes to the growth of gross domestic product as it tax rate policies on income tax and revenue collection process. Though SMEs plays a role in development of the economy, it constrains by existence of government regulations, laws and tax policies that impeded developments in the business.

Eniola [21] reviewed government policy on financial accountability of SMEs in Nigeria. The sample of 31 small and medium enterprises was used. Regression analysis was used. The study found that government policy through tax impositions have instrumental effects on financial accountability, however, the role played by revenue collection agencies are influenced by government policy through tax laws and regulations. The role of government policies vary from developed countries to the developing characterized by its social variations and industry settings. It is shown that existence of laws and regulation is a bureaucratic process which hinders entrepreneurship financial accountability. The government policy can improve and help technological solutions in production equally hindering financial accountability in policy introduction.

Mmbone [13] explored the impact of government policy on accountability of Apparel industry in Sri Lanka. The study aimed to explore the dimensions of government policy on financial accountability of an industry. A case study design was used. The study used questionnaire which was distributed to 114 employees who were randomly stratified through stratified random sampling technique.
Descriptive statistics such as mean and standard deviations were used. The findings indicated that government policies influences financial accountability through Tax policy and organizational budget.

Perotti [22] conducted a study on the effect of government policy on financial accountability in Kenya. The study adopted descriptive statistics to analyze data collected from 35 businesses was targeted for the study. The finding showed that most government revenues are influenced by budget policy because of neither deficit nor balanced budget. The projected expenditure is from allocation of ksh 7.7 but faced budget deficit on allocations. Reducing tax base can limit revenue by regulated by collection policies on cess, and levy collections. Development tax can apply in government revenue collections. Tariff free rate adjustment reflects revenue collected from land or building transfer tax, gasoline. It further noted that there was association between revenue collection and government policy in that central government collect taxes for development of project such as education, health facilities and construction of roads.

\section{RESEARCH METHODOLOGY}

The study used cross-sectional survey research design. The target population consisted of 760 Rorya District council members dealing with revenue collection matters. The sample size of 288 respondents comprised 262 respondents plus non response of 26 was used in Rorya District in Tanzania. Closed ended questionnaire was used to collect primary data. Research questions were arranged using 5 point scale likert scale.

\section{RESULTS AND DISCUSION Cess collection}

The study sought to analyze the effect of cess collection on financial accountability in Rorya District Council in Tanzania. Table 4.1 presents the results.

The respondents were asked to indicate whether the following aspects of cess collection influenced financial accountability. From the results, it was shown that fishing cess (Sangara) was well collected which indicated highest mean of 4.59 with standard deviation of .736 , followed by transparency procedure in food crop cess collection which had a mean of 4.27 with a standard deviation of 1.084, Milk cess collection was appropriately documented in database for accountability had a mean of 4.00 with a standard deviation of .946 , Cess collected from produce was accounted for and formed part of sales tax had a mean of 3.94 with a standard deviation of .989 , cess from Cotton crop was well collected at all levels had a mean of 3.77 with a standard deviation of.892, The produce cess potential was identified for future revenue collection had a mean of 3.13 with a standard deviation of 1.074 and Excise duty was collected to increase revenue collected had a mean of 2.86 with a standard deviation of 1.440 . 
Table-4.1: Aspects of Cess collection

\begin{tabular}{|l|l|l|l|l|l|}
\hline & $\mathbf{N}$ & Minimum & Maximum & Mean & $\begin{array}{l}\text { Std. } \\
\text { Deviation }\end{array}$ \\
\hline Cess collected from produce is accounted for and forms part of sales tax & 269 & 2 & 5 & 3.94 & .989 \\
\hline Fishing cess (Sangara) is well collected & 269 & 2 & 5 & 4.59 & .736 \\
\hline There is transparency procedure in food crop cess collection & 269 & 2 & 5 & 4.27 & 1.084 \\
\hline $\begin{array}{l}\text { Milk cess collection is appropriately documented in database for } \\
\text { accountability }\end{array}$ & 269 & 2 & 5 & 4.00 & .946 \\
\hline Excise duty is collected to increase revenue collected. & 269 & 1 & 5 & 2.86 & 1.440 \\
\hline The Produce cess potential is identified for future revenue collection & 269 & 1 & 5 & 3.13 & 1.074 \\
\hline Cotton crop cess is well collected at all levels & 269 & 1 & 5 & 3.77 & .892 \\
\hline Valid N (listwise) & 269 & & & \\
\hline
\end{tabular}

Source: Research Data 2020

From the results presented in table 4.1, the respondents established that cess collection from fishing (Sangara) was well indicated by the highest mean of 4.59 with standard deviation of .736 . At a mean of 4.59 was close to 5 which had maximum value in the scale resulted to conclude that majority of the respondents agreed that cess collection from fish was well achieved. However, Excise duty increased revenue collected which indicated lowest mean of 2.86 with a standard deviation of 1.440. This implied that the mean given at
2.86 was going downward to minimum value of 1 in the scale depicted respondents disagreed whether excise duty increase revenue collected in the district.

\section{Regression}

The study conducted regression analysis to determine the existence of a relationship between cess revenue collection and financial accountability in Rorya District Council in Tanzania. The results were presented in table 4.2.

Table-4.2: Model Summary

\begin{tabular}{|l|l|l|l|l|}
\hline Model & R & R Square & Adjusted R Square & Std. Error of the Estimate \\
\hline 1 & $.481^{\mathrm{a}}$ & .231 & .220 & 1.27265 \\
\hline
\end{tabular}

Source: (Field data 2020)

The calculated $\mathrm{R}$ of .481 indicates the strength of a relationship between independent variables and dependent variables. The adjusted $\mathrm{R}$ Square of .231 indicated that the degree of change in a relationship between variables. This implied that a change in revenue collection can result to a change in financial accountability by $23.10 \%$ while the remaining percentage $76.9 \%$ could be explained by other variable not in this study.

ANOVA analysis was conducted to determine the model fit of the regression line. In ANOVA, the calculated F 19.844, P.000 in table 4.3 showed that the regression model was fit to predict the relationship between revenue collection and financial accountability.

Table-4.3: ANOVA ${ }^{\mathrm{a}}$

\begin{tabular}{|c|c|c|c|c|c|c|}
\hline \multicolumn{2}{|c|}{ Model } & Sum of Squares & Df & Mean Square & $\mathbf{F}$ & Sig. \\
\hline \multirow{3}{*}{1} & Regression & 128.557 & 4 & 32.139 & 19.844 & $.000^{\mathrm{b}}$ \\
\hline & Residual & 427.583 & 264 & 1.620 & & \\
\hline & Total & 556.140 & 268 & & & \\
\hline \multicolumn{7}{|c|}{ a. Dependent Variable: Financial Accountability } \\
\hline \multicolumn{7}{|c|}{ b. Predictors: (Constant), Cess Collection } \\
\hline
\end{tabular}

Source: (Field data 2020)

The study also conducted regression coefficients to determine the variation of independent variables on dependent variable under regression equation. Table 4.4 presented the results.

Table-4.4: Regression Coefficients ${ }^{\mathrm{a}}$

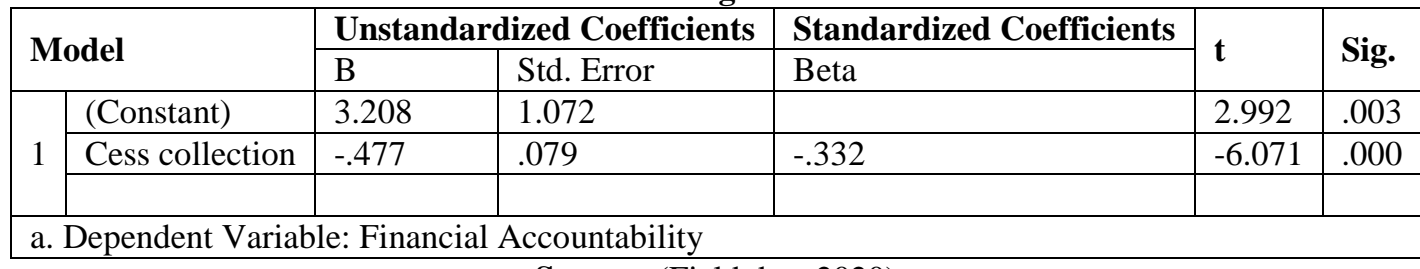

Source: (Field data 2020) 
Direct model was presented as follows;

$\mathrm{Y}=3.208-.477 \mathrm{X}_{1}+\varepsilon$

The results show that a change in unit of cess collection would result to a change in financial accountability by -.477 . This implied that a change in Cess collection would result to a decrease in financial accountability by $47.7 \%$ and was statistically significant at $5 \%$.

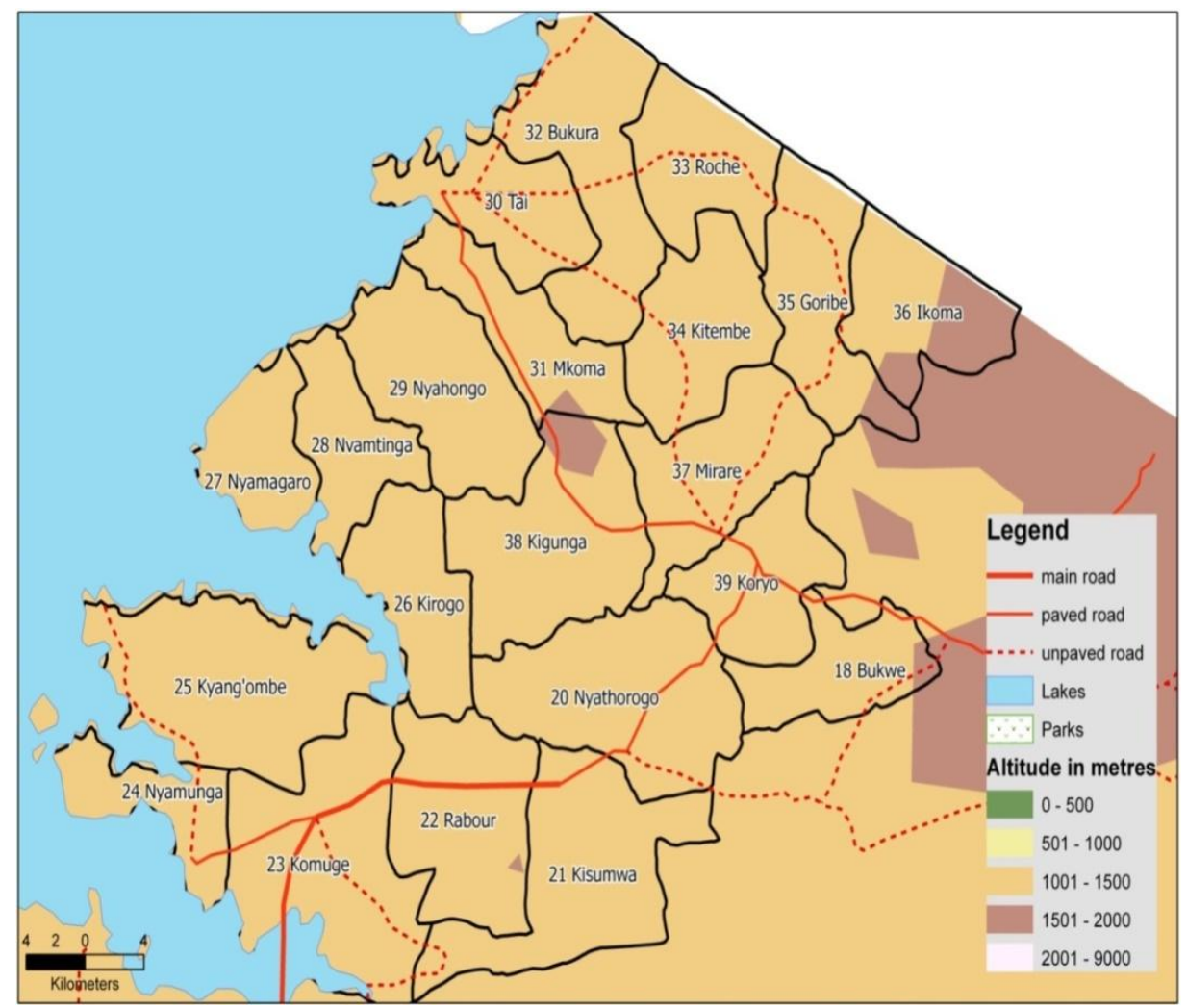

\section{CONCLUSION AND \\ RECOMMENDATION \\ Conclusion of study}

The study concluded that cess collection was from fishing (Sangara). The cess collected from fish was well achieved by excise duty increased revenue collected in the district. There was a negative relationship between Cess collection and financial accountability which was statistically significant. Cess collection had a statistically significant effect on financial accountability.

\section{Recommendation of study Managerial Implication}

The study indicated that excise duty increased revenue collected which was indicated by the lowest mean. The study recommended that excise duty should be enhanced in order to increase revenue collection in the district. In correlation analysis, it was shown that cess collection on financial accountability which was negative. This study recommended that Cess collection should be managed well in order to improve financial accountability. the evidenced council economic committee reports 2018 and 2019 indicated lack of mass productions of cash and food crop that accelerate cess generations should be improved by attracting investment in agricultural sector and small industries.

\section{REFERENCES}

1. Garcia, M. M., \& Von Haldenwang, C. (2016). Do democracies tax more? Political regime type

2. Benedek, D., Crivelli, E., Gupta, S., \& Muthoora, P. (2014). Foreign aid and revenue: Still a crowding-out effect?. FinanzArchiv: Public Finance Analysis, 70(1), 67-96.

3. Rossotti, C. O. (2005). Many unhappy returns: One man's quest to turn around the most unpopular organization in America. Harvard Business School Press

4. Rosen, J. M., \& Jordan, C. T. (2009). The increasing complexity of the cancer stem cell paradigm. Science, 324(5935), 1670-1673.

5. Okezie, U., Akanbi, C. T., Otunola, E. T., \& Adeyemi, I. A. (2003). Effect of addition of ripe bananas on some physico-chemical properties of maize 'extract'. International journal of food sciences and nutrition, 54(6), 437-445.

6. Meena, P. (2013). Assessment of the challenges facing revenue collection in Tanzania: evidence from Tanzania revenue authority (TRA); Morogoro. Doctoral dissertation, Mzumbe University.

7. Priestley, M., \& Biesta, G. (Eds.). (2013). Reinventing the curriculum: New trends in curriculum policy and practice. A \& C Black. 
8. Prichard, W., Cobham, A., \& Goodall, A. (2014). The ICTD Government revenue dataset, WKP Report, No. 3

9. Piketty, T., Saez, E., \& Zucman, G. (2017). Distributional national accounts: methods and Estimates for the United States. The Quarterly Journal of Economics, 33(2), 553-609.

10. Kidd M and William Crandall. (2016). Revenue Authorities: Issues and Problems in Evaluating their Success, International Monetary Fund working paper No. 72

11. Mutisya J. M. (2014),'Effects of an integrated Revenue collection system and challenges facing its implementation in Machakos County" unpublished Project University of Nairobi.

12. Prichard, W. (2016). Reassessing tax and development research: A new dataset, new findings, and lessons for research. World Development Journal, 8(9) 48-60.

13. Mlay, R. M. (2015). Factors enhancing tax payment compliance for Medium taxpayers in Tanzania: The case of Tanzania revenue authority, Kilimanjaro region. Doctoral Dissertation submitted to Mzumbe University

14. Ataro, E., Madara, S. D., \& Sitati, S. (2016). Design and testing of mobile-phone-detectors.

15. Khamis, J. (2014). Assessment of quality of tax payers' services on the Performance of Tanzania revenue authority: the case of Zanzibar Doctoral dissertation, Mzumbe University.

16. Clist, P. (2016). Foreign aid and domestic taxation: Multiple sources, one conclusion. Development Policy Review, 34(3), 365-383.

17. Saez, E. (2016). Statistics of Income Tabulations: High Incomes, Gender, Age, Earnings Split, and Nonfilers,". SOI Working Paper 5.

18. Harrison, R. (2013). Crowdfunding and the revitalisation of the early stage risk capital market: catalyst or chimera?

19. Munene, R., \& Nduruhu, D. (2016). Effect of Tax Reforms on Revenue Collection at Customs and Border Control Department of Kenya Revenue Authority. Journal of Business and Management, 18(4), 61-66.

20. Ezzamel, M., \& Willmott, H. (2013). Corporate governance and financial accountability: recent reforms in the UK public sector. Journal of Accounting, Auditing \& Accountability, 6(3) 12-25

21. Eniola, A. A., \& Entebang, H. (2015). SME firm performance-financial innovation and challenges. Procedia-Social and Behavioral Sciences, 195, 334-342.

22. Perotti, E., Cemfi, J. S., Jenkinson, N., Borio, C., Rochet, J. C., \& Stein, J. (2009). Liquidity risk charges as a macroprudential tool. 